\title{
Regular article \\ Revealing contrasting genetic variation and study of genetic diversity in urdbean (Vigna mungo (L.)Hepper) using SDS-PAGE of seed storage proteins
}

\author{
Swapan K. Tripathy*, P. Mohanty, M. Jena, G. B. Dash, K. Pradhan, P. \\ K. Nayak, Sashmita Dash, D. Lenka, D. Mishra, P.M. Mohapatra, D. \\ Swain and N. Senapati
}

In-vitro culture and Molecular Breeding Laboratory, Department of Agricultural Biotechnology, College of Agriculture, OUAT, Bhubaneswar (Odisha), INDIA

*Corresponding author email: swapankumartripathy@gmail.com

Total seed storage protein profiles of 20 urdbean genotypes including the popular variety T9 were analysed by Sodium dodecyl sulphate polyacrylamide gel electrophoresis (SDS-PAGE). 14 genotypes could be clearly identified based on genotype-specific seed protein fingerprints while rest of the test genotypes were categorized into three protein types. Dendrogram based on electrophoretic data clustered the genotypes into seven groups at 78.5\% phenon level. TU 95-1 with TU 12-25-4 revealed lowest similarity index value $(0.33)$ followed by TU 95-1 with PU 30 and KU 96-3(SI=0.35). Clustering pattern revealed distinctly divergent group formed by TPU 95-1 and TPU 4. These may serve as a valuable source genotype in recombination breeding.

Key words: Seed storage protein profiling, SDS-PAGE, Genetic variation, urdbean.

Urdbean (Vigna mungo (L.)Hepper) is a self-pollinating crop and widely cultivated grain legume (Naget al., 2006). The crop is resistant to adverse climatic conditions and improves the soil fertility by fixing atmospheric nitrogen in the soil. It is one of the rich source of vegetable protein and some essential minerals and vitamins. Morphological characters are in vogue used for selection of desirable traits (Nisaret al., 2008). Assessment of genetic diversity based on morphological characters is often less efficient and biased in assessment of genetic relationship owing to their high environmental interaction. Currently, several biochemical loci encoding seed storage proteins, soluble proteins and isozymes are available to measure genetic variation between closely related germplasm resources. Among these, the protocol of polypeptide banding pattern of seed storage proteins is simple, easy and cost effective. Besides, it can reveal a considerable degree of polymorphism and a simple genetic control subject to minimum environmental influence. It does not require DNA amplification or radio-isotope labeling for DNA profiling of genotypes. Germplasm being a vital source of valuable genes for which characterization of plant genetic resources is indispensable to improve production level and quality of the crop produce. The present study was, therefore, carried out to assess genetic variation and study of genetic diversity using 
SDS-PAGE of total seed storage protein for identification of elite divergent urdbean genotypes for further use in hybridization programme.

\section{Materials and Methods}

Seeds of 20 urdbean genotypes including a popular variety 'T9'(Table 1) were grounded to fine powder and total seed storage protein was extracted with extraction buffer (0.5M Tris- $\mathrm{HCl}$ ( $\mathrm{pH}$ 6.8), 2.5\% SDS, $10 \%$ glycerol and 5\% $\beta$-mercaptoethanol), denatured with a cracking buffer $(0.125 \mathrm{M}$ Tris $\mathrm{HCl}, \mathrm{pH} 6.8,4 \%$ SDS, 20\% glycerol, 10\% 2Mercaptoethanol, $0.1 \%$ bromophenol blue) at $100{ }^{\circ} \mathrm{C}$ for $20 \mathrm{sec}$ in hot water bath. Total seed protein was then analysed through $12.5 \%$ polyacrylamide gel in a mini vertical electrophoresis apparatus (Tarsons Ltd., India) following Laemmli (1970) with minor modifications at $100 \mathrm{v}$ for four hours. Each set of genotypes were run twice simultaneously on two separate gels under similar electrophoretic conditions to check up reproducibility. After electrophoresis, the gels were stained with silver staining technique following Blum et al., 1987 with minor modification. The gels were placed on trans-illuminator for assessment of banding pattern and photographed with Digital Camera (Canon, 7.1 megapixel). The molecular weights of the dissociated polypeptides were determined by using molecular weight marker of protein standards which consisted three standard proteins of known molecular weight i.e., ovalbumin $(43 \mathrm{kD})$, bovine serum albumin (66kD) and phosphorylase-b (97.4kd).

The genotypes were categorized according to polypeptide banding pattern of seed storage protein. The binary data matrix for presence( 1 /absence( 0 ) of bands were analysed to estimate Jaccard's similarity coefficient (Jaccard,1908) values and clustering of genotypes(dendrogram) was carried out using Unweighted Paired Group Method with Arithmetic means (UPGMA)- phenograms (Sokal and Michener, 1958)employing Sequential Agglomerative Hierarchic and Non-overlapping clustering (SAHN)(NTSYSpc2.02e).

\section{Results and Discussion}

Seed storage protein profiling has been standardized in urdbean (Ghafoor and Ahmad, 2005), grasspea (Roy et al., 2001; Emre, 2009), mungbean (Tripathy et al., 2010a; Tripathy et al., 2010c), lentil (Yuzbasioglu et al., 2008) and adzuki beans (Sai-Ut, 2009). In the present investigation, SDS-PAGE of total seed storage protein revealed altogether 18 scorable polypeptide bands with molecular weights ranging from 32.5 to $132 \mathrm{kD}$ (Fig 1, Table 1). This envisaged that at least 21 multi-gene families are involved in seed storage protein expression in pigeon pea. However, Gangwar and Bajpai (2006) observed 26 polypeptide bands both high as well as low molecular weight ranging from 11.0 to $98.0 \mathrm{kD}$. Four polypeptide bands at molecular weight positions 86.5, 48.0, 45.5 and $32.5 \mathrm{kD}$ were found to be monomorphic among which $45.5 \mathrm{kD}$ band was characteristically broad and dense. Rest of the bands had shown polymorphism to the extent of $77.8 \%$ among the test genotypes. It indicated that the genes controlling the expression of the above four monomorphic protein bands appeared to behave in single blocks.

\section{Genetic variation in seed storage protein expression:}

Variation in polypeptide banding pattern in other legumes (frenchbean, Vicia faba, chick pea, urdbean and mungbean) have been reported by many workers (Koenig et al., 1990; Polignano et al., 1990; Ladizinsky and Adler, 1975; Thakare et al., 1988; Tripathy et al., 2010a), but report on urdbean is scanty. However, wide range of intra-specific variation in protein profiles was observed in the present pursuit. As a whole, the resulting data matrix of the presence and absence of 
bands resolved 167 polymorphic polypeptide bands out of total 247 bands over all the 20 test genotypes used in the study which reveals $67.61 \%$ polymorphism.

The present study using silver staining technique revealed great array of polymorphism in terms of qualitative (presence/absence and colour of bands) and quantitative (colour intensity and thickness of bands) differences in polypeptides dissociated following cleavage of storage

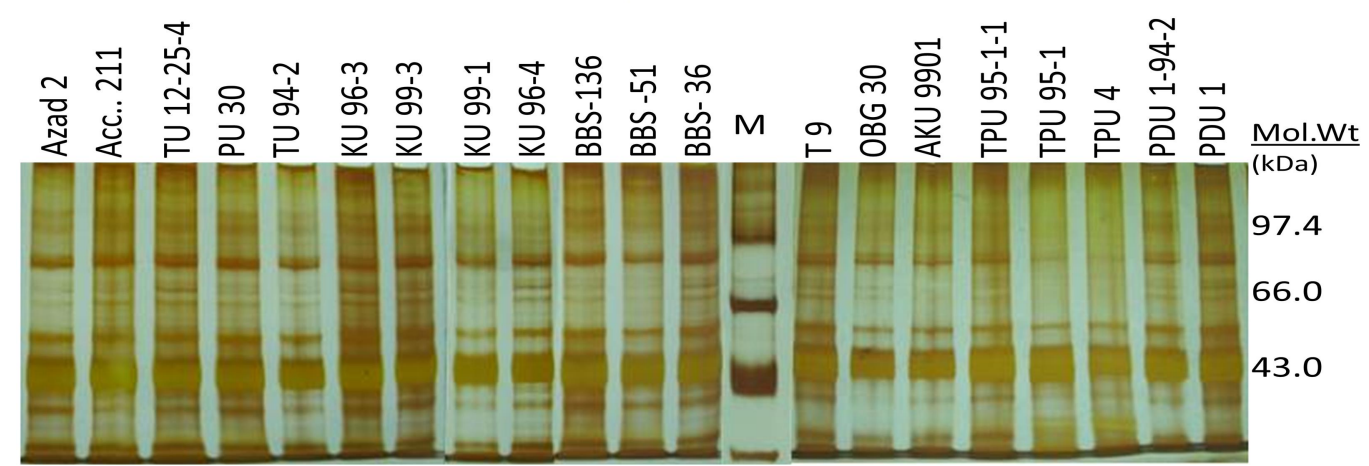

Fig 1. Seed storage protein profiles of 20 urdbean genotypes (lane 1-12 and lane 14-20), Lane 13: Molecular wt. marker (M).

In the present investigation, number of polypeptide bands in each genotype ranged from seven (TPU 95-1) to as high as 17 bands (TU 12-25-4) with an average of 12.35 bands/genotype. Besides, PU 30 and KU 96-3 recorded 16 polypeptide bandseach. These genotypes varied in polypeptide banding pattern and may be considered superior in protein quality provided the polypeptides revealed are not associated with anti-nutritional properties. Proteins being the direct gene products reflect the genomic composition of lines accurately to some extent and therefore, are ideal for study of genotypic distinctiveness. 17 protein types/profiles were detected for seed protein expression in the present set of test genotypes. Frequency of genotypes revealing each band was shown to be as minimum as 2 to maximum 20 indicating wide range of seed protein expression among the test genotypes. Fourteen test genotypes revealed their characteristic genotype-specific protein fractions (Fig 1). Roy et al. (2001) also noted differences in band mobility, width and intensity in legumes. The observed differences in protein band intensity could be utilized in identification of high protein rich genotypes. In the present pursuit, the $86.5 \mathrm{kD}$ band is comparatively thicker in all genotypes except TPU 95-1 and TPU 4. Such types of close relationships and/or minor variations were also observed in chickpea (Kharkwal, 1999). 
Table 1. Electrophoretic (SDS-PAGE) polypeptide banding pattern of total seed storage protein in a set of 20 urdbean genotypes.

\begin{tabular}{|c|c|c|c|c|c|c|c|c|c|c|c|c|c|c|c|c|c|c|c|c|c|c|}
\hline \multirow{2}{*}{ 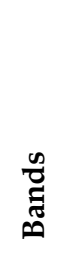 } & \multirow[t]{2}{*}{ 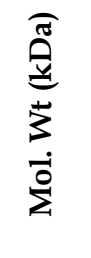 } & 总 & $\begin{array}{l}F \\
\vec{\sim} \\
\dot{u} \\
\dot{\psi}\end{array}$ & 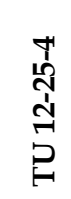 & $\begin{array}{l}\text { p } \\
\text { D }\end{array}$ & \begin{tabular}{l}
$\mathfrak{Y}$ \\
\multirow{1}{*}{} \\
$己$ \\
$\mathfrak{H}$
\end{tabular} & $\begin{array}{l}\text { p. } \\
\text { o̊ } \\
2 \\
2\end{array}$ & $\begin{array}{l}\text { ô } \\
\text { જે } \\
2\end{array}$ & 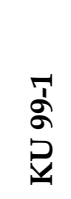 & $\begin{array}{l}\text { tr } \\
\text { o̊ } \\
己 \\
\qquad\end{array}$ & $\begin{array}{l}\stackrel{0}{1} \\
n \\
n \\
0\end{array}$ & $\begin{array}{l}\bar{n} \\
\infty \\
\infty \\
\infty\end{array}$ & $\begin{array}{l}\infty \\
\infty \\
\infty \\
\infty\end{array}$ & $a$ & $\begin{array}{l}0 \\
\text { 0 } \\
0 \\
0 \\
0\end{array}$ & $\begin{array}{l}\bar{\sigma} \\
\delta \\
2 \\
2 \\
2\end{array}$ & 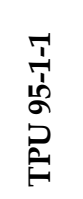 & 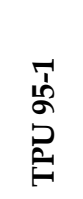 & $\begin{array}{l}+ \\
D \\
D\end{array}$ & 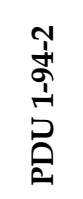 & 号 & 吾 \\
\hline & & V1 & V2 & V3 & V4 & V5 & V6 & V7 & V8 & V9 & V10 & V11 & V12 & V13 & V14 & V15 & V16 & V17 & V18 & V19 & V20 & \\
\hline B1 & 132.0 & 0 & 1 & 1 & 0 & 0 & 1 & 1 & 0 & 0 & 1 & 1 & 1 & 0 & 0 & 0 & 0 & 0 & 0 & 0 & 0 & 7 \\
\hline B2 & 123.3 & 0 & 1 & 1 & 1 & 0 & 1 & 1 & 0 & 0 & 1 & 1 & 1 & 0 & 0 & 0 & 0 & 0 & 0 & 1 & 1 & 10 \\
\hline B3 & 108.0 & 1 & 1 & 1 & 1 & 1 & 1 & 1 & 1 & 1 & 1 & 1 & 1 & 1 & 1 & 1 & 1 & 0 & 0 & 1 & 1 & 18 \\
\hline B4 & 102.2 & 1 & 1 & 1 & 1 & 1 & 1 & 1 & 1 & 1 & 1 & 1 & 1 & 1 & 1 & 1 & 1 & 0 & 0 & 1 & 1 & 18 \\
\hline B5 & 95.0 & 0 & 0 & 1 & 1 & 1 & 1 & 0 & 1 & 1 & 0 & 0 & 0 & 0 & 0 & 0 & 0 & 0 & 0 & 0 & 0 & 6 \\
\hline B6 & 86.5 & 1 & 1 & 1 & 1 & 1 & 1 & 1 & 1 & 1 & 1 & 1 & 1 & 1 & 1 & 1 & 1 & 1 & 1 & 1 & 1 & 20 \\
\hline B7 & 75.8 & 1 & 1 & 1 & 1 & 1 & 1 & 1 & 0 & 1 & 1 & 1 & 1 & 1 & 0 & 0 & 1 & 0 & 1 & 1 & 1 & 16 \\
\hline B8 & 73.0 & 1 & 1 & 1 & 1 & 1 & 1 & 1 & 1 & 1 & 1 & 1 & 1 & 1 & 1 & 0 & 1 & 0 & 0 & 1 & 1 & 17 \\
\hline B9 & 680 & 1 & 1 & 1 & 1 & 1 & 1 & 1 & 1 & 1 & 1 & 1 & 1 & 1 & 1 & 1 & 1 & 0 & 1 & 1 & 1 & 19 \\
\hline B10 & 59.2 & 0 & 1 & 1 & 1 & 0 & 1 & 1 & 0 & 1 & 1 & 1 & 1 & 0 & 0 & 0 & 0 & 0 & 0 & 0 & 1 & 10 \\
\hline B11 & 55.0 & 0 & 1 & 1 & 1 & 0 & 0 & 0 & 0 & 0 & 0 & 0 & 0 & 0 & 0 & 0 & 0 & 0 & 0 & 0 & 0 & 3 \\
\hline B12 & 48.0 & 1 & 1 & 1 & 1 & 1 & 1 & 1 & 1 & 1 & 1 & 1 & 1 & 1 & 1 & 1 & 1 & 1 & 1 & 1 & 1 & 20 \\
\hline B13 & 45.5 & 1 & 1 & 1 & 1 & 1 & 1 & 1 & 1 & 1 & 1 & 1 & 1 & 1 & 1 & 1 & 1 & 1 & 1 & 1 & 1 & 20 \\
\hline B14 & 43.0 & 0 & 0 & 1 & 1 & 1 & 1 & 1 & 1 & 0 & 1 & 0 & 0 & 0 & 0 & 0 & 0 & 0 & 0 & 0 & 1 & 8 \\
\hline B15 & 38.2 & 1 & 1 & 1 & 1 & 1 & 1 & 1 & 1 & 1 & 1 & 1 & 1 & 1 & 0 & 1 & 1 & 1 & 1 & 1 & 1 & 19 \\
\hline B16 & 35.5 & 1 & 1 & 1 & 1 & 1 & 1 & 1 & 0 & 1 & 1 & 1 & 1 & 0 & 0 & 0 & 0 & 1 & 1 & 0 & 1 & 14 \\
\hline B17 & 34.0 & 0 & 0 & 0 & 0 & 0 & 0 & 0 & 0 & 0 & 0 & 0 & 0 & 0 & 0 & 0 & 0 & 1 & 1 & 0 & 0 & 2 \\
\hline B18 & 32.5 & 1 & 1 & 1 & 1 & 1 & 1 & 1 & 1 & 1 & 1 & 1 & 1 & 1 & 1 & 1 & 1 & 1 & 1 & 1 & 1 & 20 \\
\hline & tal & 11 & 15 & 17 & 16 & 13 & 16 & 15 & 11 & 13 & 15 & 14 & 14 & 10 & 8 & 8 & 10 & 7 & 9 & 11 & 14 & 247 \\
\hline
\end{tabular}


Table 2. Similarity coefficients between paired test genotypes for total seed storage protein banding pattern in a set of 20 urdbean genotypes.

\begin{tabular}{|c|c|c|c|c|c|c|c|c|c|c|c|c|c|c|c|c|c|c|c|c|}
\hline $\begin{array}{l}\dot{0} \\
\dot{Z} \\
\dot{\omega}\end{array}$ & 总 & ָัָ & 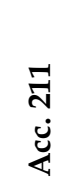 & 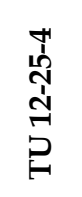 & $\begin{array}{l}\text { లి } \\
\text { ? }\end{array}$ & 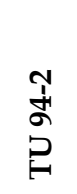 & $\begin{array}{l}\text { â } \\
\text { o } \\
2 \\
2\end{array}$ & $\begin{array}{l}\text { ô } \\
\text { ó } \\
2\end{array}$ & $\begin{array}{l}\text { જ̄ } \\
\text { જે } \\
\text { 己ે }\end{array}$ & 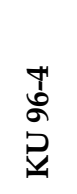 & $\begin{array}{l}\text { Dे } \\
\text { ஸे } \\
\infty \\
\infty\end{array}$ & 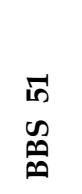 & 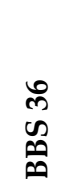 & $\stackrel{a}{n}$ & $\begin{array}{l}0 \\
0 \\
0 \\
0\end{array}$ & 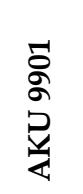 & 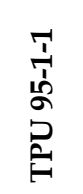 & 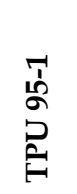 & $\begin{array}{l}+1 \\
\stackrel{1}{2}\end{array}$ & 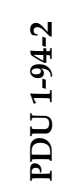 \\
\hline & & V1 & V2 & V3 & V4 & V5 & V6 & V7 & V8 & V9 & V10 & V11 & V12 & V13 & V14 & V15 & V16 & V17 & V18 & V19 \\
\hline V2 & Acc. 211 & 0.73 & & & & & & & & & & & & & & & & & & \\
\hline V3 & TU 12-25-4 & 0.64 & 0.98 & & & & & & & & & & & & & & & & & \\
\hline V4 & PU 30 & 0.68 & 0.82 & 0.94 & & & & & & & & & & & & & & & & \\
\hline V5 & TU 94-2 & 0.84 & 0.64 & 0.76 & 0.81 & & & & & & & & & & & & & & & \\
\hline V6 & KU 96-3 & 0.68 & 0.82 & 0.94 & 0.88 & 0.81 & & & & & & & & & & & & & & \\
\hline V7 & KU 99-3 & 0.73 & 0.87 & 0.88 & 0.82 & 0.75 & 0.93 & & & & & & & & & & & & & \\
\hline V8 & KU 99-1 & 0.69 & 0.52 & 0.64 & 0.68 & 0.84 & 0.68 & 0.62 & & & & & & & & & & & & \\
\hline V9 & KU 96-4 & 0.84 & 0.75 & 0.76 & 0.81 & 0.85 & 0.81 & 0.75 & 0.71 & & & & & & & & & & & \\
\hline V10 & BBS 136 & 0.73 & 0.87 & 0.88 & 0.82 & 0.75 & 0.93 & 1.00 & 0.62 & 0.75 & & & & & & & & & & \\
\hline V11 & BBS 51 & 0.88 & 0.93 & 0.82 & 0.76 & 0.68 & 0.87 & 0.93 & 0.56 & 0.80 & 0.93 & & & & & & & & & \\
\hline V12 & BBS 36 & 0.78 & 0.93 & 0.82 & 0.76 & 0.68 & 0.87 & 0.93 & 0.56 & 0.80 & 0.93 & 1.00 & & & & & & & & \\
\hline V13 & T 9 & 0.90 & 0.66 & 0.58 & 0.62 & 0.76 & 0.62 & 0.66 & 0.75 & 0.76 & 0.66 & 0.71 & 0.71 & & & & & & & \\
\hline V14 & OBG 30 & 0.72 & 0.53 & 0.47 & 0.50 & 0.61 & 0.50 & 0.53 & 0.72 & 0.61 & 0.53 & 0.57 & 0.57 & 0.80 & & & & & & \\
\hline V15 & AKU 9901 & 0.72 & 0.53 & 0.47 & 0.50 & 0.61 & 0.50 & 0.53 & 0.72 & 0.61 & 0.53 & 0.57 & 0.57 & 0.80 & 0.77 & & & & & \\
\hline V16 & TPU 95-1-1 & 0.90 & 0.68 & 0.58 & 0.62 & 0.76 & 0.62 & 0.66 & 0.75 & 0.76 & 0.66 & 0.71 & 0.71 & 1.00 & 0.80 & 0.80 & & & & \\
\hline V17 & TPU 95-1 & 0.50 & 0.37 & 0.33 & 0.35 & 0.42 & 0.35 & 0.37 & 0.38 & 0.42 & 0.37 & 0.40 & 0.40 & 0.41 & 0.36 & 0.50 & 0.41 & & & \\
\hline V18 & TPU 4 & 0.66 & 0.50 & 0.44 & 0.47 & 0.57 & 0.47 & 0.50 & 0.42 & 0.57 & 0.50 & 0.53 & 0.53 & 0.58 & 0.41 & 0.54 & 0.58 & 0.77 & & \\
\hline V19 & PDU 1-94-2 & 0.83 & 0.73 & 0.64 & 0.68 & 0.71 & 0.68 & 0.73 & 0.69 & 0.71 & 0.73 & 0.78 & 0.78 & 0.90 & 0.72 & 0.72 & 0.90 & 0.38 & 0.53 & \\
\hline V20 & PDU 1 & 0.78 & 0.81 & 0.82 & 0.87 & 0.80 & 0.87 & 0.93 & 0.66 & 0.80 & 0.93 & 0.86 & 0.86 & 0.71 & 0.57 & 0.57 & 0.71 & 0.40 & 0.53 & 0.78 \\
\hline
\end{tabular}


Genetic variation in a set of germplasm has an important role in identification of varieties. Polymorphism in electrophoretic banding pattern of seed storage proteins is associated with the genetic background of proteins and thus, this can be used to certify the genetic makeup (Javid, 2004 and Iqbal, 2005). TU 12-25-4 can be differentiated from PU 30 by absence of a high mol. wt polypeptide band at $132.5 \mathrm{kD}$ position. ACC 211, TU 12-25-4 and PU 30 revealed a unique $55 \mathrm{kD}$ band and this was absent in all other test genotypes. Similarly, $34.0 \mathrm{kD}$ band was unique to TPU 95-1 and TPU 4. In contrast, a $38.2 \mathrm{kD}$ polypeptide band was shown to be specifically present in all genotypes except OBG 30. Such genotype -specific protein markers could be reliably used for varietal certification and maintenance of pure seeds in seed multiplication programme.
Genetic similarity/distance: Genetic distance is the inverse measure of genetic similarity. Similarity index values between paired genotypes ranged from 0.33 to as high as 1.0 in between few combinations (Table 2). In fact, only 24 out of possible 190 paired genotypic combinations have similarity coefficient value less than 0.50 indicating fair degree of homology among the test materials. TPU 95-1 followed by TPU 4 are the most divergent genotypes which revealed least average genetic similarity (0.41) with rest of the genotypes. Among all possible combinations; TU 95-1 (V17) with TU 12-25-4 (V3) revealed lowest similarity index value (0.33) followed by TU 95-1 with PU 30 and KU 96-3(SI=0.35). Such genotypic combinations could be selected in hybridization programme.

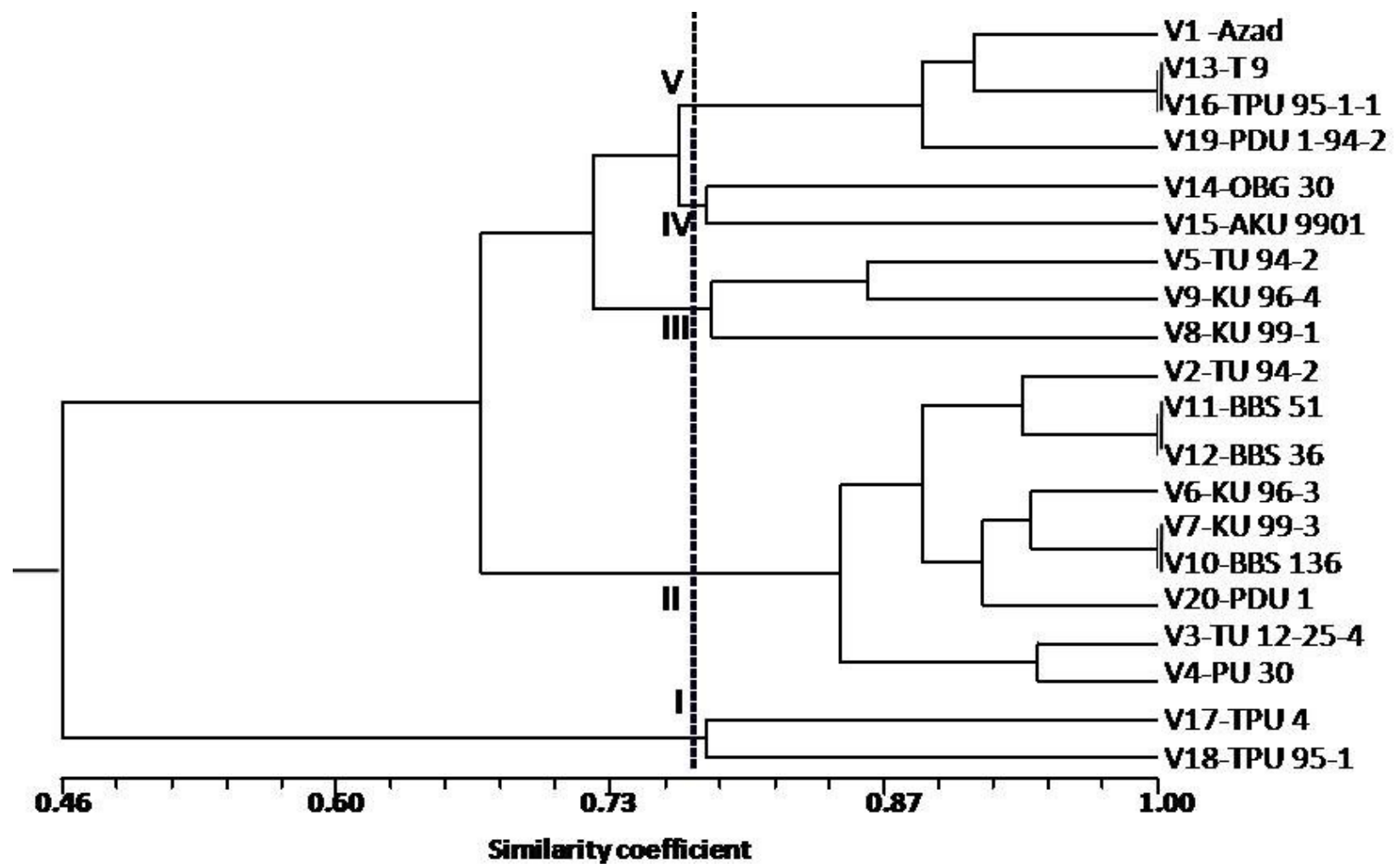

Fig 2. Dendrogram showing genetic diversity of urdbean genotypes based on total seed storage protein fingerprinting. 
Clustering pattern: Genetic diversity is the diversity of the sets of genes carried by different genotypes of a species (Panda, 2013). Information of genetic resources with broad genetic diversity is a pre-requisite for accelerated genetic improvement of crops. The dendrogram showing genetic relationship among 20 test genotypes for total seed storage protein expression is presented in Fig 2. Initially, the genotypes were distributed into five clusters e.g., Cluster I, Cluster II, Cluster III, Cluster IV and Cluster $\mathrm{V}$ within $78.5 \%$ phenon level. Initially, TPU 95-1 and TPU 4 separated out from rest of the test genotypes at $46 \%$ phenon level forming cluster I. Cluster-II was shown to be the next divergent group which included nine test genotypes. Cluster III Cluster-IV and Cluster V more or less maintained high inter-cluster homology. However, cluster VI was the largest cluster which included eighteen genotypes. Genotypes included under Cluster V find their position opposite extreme end of the dendrogram in comparison to Cluster I. In the present investigation, T 9 and TPU 95-1-1; BBS 51 and BBS 36; and both KU 99-3 and BBS 136 pair-wise clubbed together even at $100 \%$ phenon level as these exhibited exactly similar protein profiles. Therefore, SDSPAGE in combination with 2-D electrophoresis is further suggested for documenting contrasting variation of isoforms of protein polypeptides.

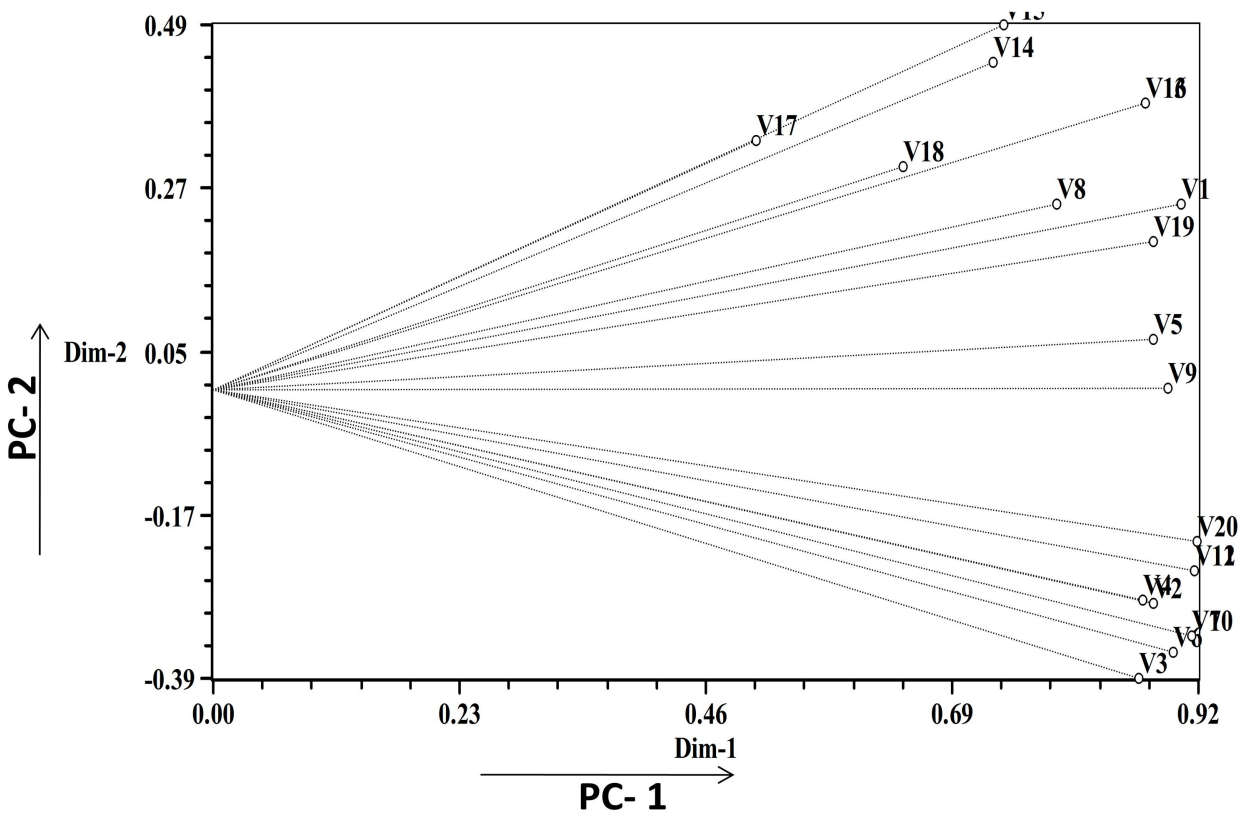

Fig 3. Two-dimensional scaling of principal co-ordinates(PC 1 and PC 2) using seed storage protein markers.

Ghafoor et al. (2002) obtained four clusters in a set of genotypes of Vigna mungo and $V$. radiata resembling to $V$. mungo for seed characters. Asghar et al. (2003) classified 29 genotypes of chickpea into five clusters based on 18 polypeptide bands. They reported presence/ absence of specific bands in genotypes comprising different clusters.
However, Ghallab et al. (2007) observed three different genetic clusters in 10 genotypes of mungbean. They had shown grouping of two genotypes L 3430 and L 2920 into a specific cluster owing to their similar polypeptide banding pattern. Tripathy et al. $(2010 \mathrm{a}, \mathrm{b})$ also reported clustering of few mungbean genotypes e.g., Pant M 5 and RCM 15 into a 
single cluster due to their characteristic polypeptide banding pattern.

An effort was made to verify the protein profiles of the test genotypes in relation to their distribution in the dendrogram clusters., As expected, some of the genotypes with common protein type clubbed together in the dendrogram at $100 \%$ phenon level (Fig 2), whereas the rest of the genotypes isolated as single variety clusters were shown to have distinct unique protein types (Table 1). The positioning of unique protein type genotypes in the dendrogram was shown to have some relation with their mean genetic dissimilarity with rest of the test genotypes.

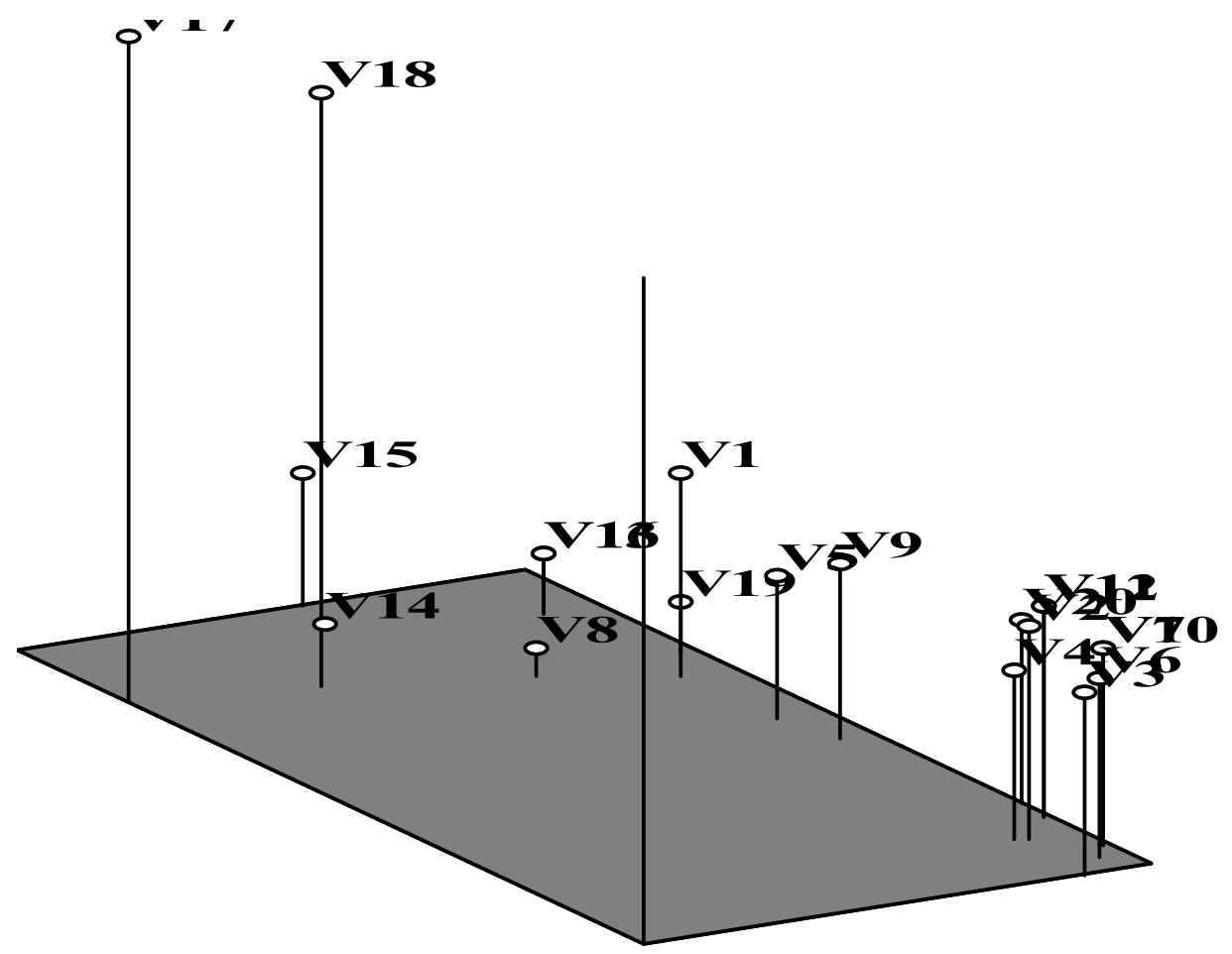

Fig 4. Three-dimensional scaling of principal co-ordinates (PC 1 ,PC 2 and PC 3) using seed storage protein markers.

Besides, the grouping of genotypes using two- and three dimensional scaling based on PCA values (Fig. 3 \&4) was found to be more or less consistent with that of UPGMA analysis. The three dimensional scaling represented clear grouping of test genotypes. TPU 95-1 and TPU 4 which were initially separated from rest of the test genotypes in case of UPGMA clustering (Fig.2), were also seen to be screened out to diverse extreme positions in PCA analysis. These genotypes could serve as a valuable source of genetic material for recombination breeding and other innovative approaches of crop improvement programme in urdbean.

\section{References}

Asghar R, Tayyaba S and Afzal M. 2003. Inter and intra-specific variation on SDS-PAGE electrophoregrams of seed protein in chickpea (Cicer arietinum L.) germplasm. Pakistan Journal of Biological Science 6(24): 1991-1995.

Blum H, Beier H and Gross HJ. 1987. Improved silver staining of plant proteins, RNA and DNA in polyacrylamide gels. Electrophoresis 8(2): 93-99.

Emre I. 2009. Electrophoretic analysis of some Lathyrus species based on seed storage proteins. Genetic Resources and Crop Evolution 56: 31-38. 
Gangwar L K and Bajpai G C. 2006. Seed protein variation in interspecific hybrids of pigeonpea. Indian Journal Crop Science 1 (1-2): 125-128.

Ghafoor A, Ahmed Z, Qureshi AS and Bashir M. 2002.Genetic relationship in Vigna mungo (L.) Hepper and $V$. radiata (L.) Wilczek based on morphological traits and SDS-PAGE. Euphytica 123 (3): 367-378.

Ghafoor A and Ahmad Z. 2005. Diversity of agronomic traits and total seed proteins in blackgram (Vigna mungo (L.) Hepper). Acta Biologia Cracoviensia series Botanica 47:69-75.

Ghallab K H, Ekram A M, Afiah S A and Ahmed S M. 2007. Characterization of some superior mungbean genotypes on the agronomic and biochemical genetic levels. Egyptian Journal of Desert Research 57(2): 1-11.

Jaccard P. 1908. Nouvellesrecherches Sur la distribution florale. Bulletin Society Vaud Science National 44: 223-270.

Javid A, Ghafoor A and Anwar R 2004.Seed storage protein electrophoresis in groundnut for evaluating genetic diversity. Pakistan Journal of Botany 36: 87-96.

Iqbal SM, Ghafoor A and Ayub N. 2005. Relationship between SDS-PAGE markers and Ascochyta blight in chickpea. Pakistan Journal of Botany 37(1): 87-96.

KaruppanapandianT, Karuppudurai T, Sinha P B, Haniya AMK and Manoharan K. 2006. Phylogenetic diversity and relationships among cowpea (Vigna unguiculata (L.).Walp.) landraces using random amplified polymorphic DNA markers. General Applied Plant Physiology 32(3-4): 141-152.

Kharkwal M C. 1999. Seed storage protein intraspecific relationship in chickpea. Journal of Genetics \& Plant Breeding 59: 59-63.

Koenig R L, Singh S P and Gepts P. 1990. Novel phaseolin types in wild and cultivated common bean (Phaseolus vulgaris, Fabaceae). Economic Botany 44: 50-60.

Ladizinsky G and Adler A. 1975.The origin of chickpea as indicated by seed protein electrophoresis. Israel Journal of Botany 24: 183-189.

Laemmli UK, 1970. Cleavage of structural protein during the assembly of the read of bacteriophage. Nature 227: 680-685.

Nag N, Sharma SK and Kant A. 2006. Agronomic evaluation of some induced mutants of urdbean (Vigna mungo (L.) Hepper). Society for the Advancement of Breeding Research in Asia and Oceania. Journal of Breeding and Genetics 38: 29-38.

Naik BS. 1998. Genetic characterization of cultivars and seed protein in mungbean. Ph.D. Thesis, Utkal Univ., Vani Vihar, Bhubaneswar, India, p: 5-85.

Nisar MA, Ghafoor H, Ahmad KM, Rashid AS, Qureshi and Ali H. 2008. Evaluation of genetic diversity of pea germplasm through phenotypic traits analysis. Pakistan Journal of Botany 40(5): 20812086.

Panda A. 2013. Study of genetic diversity of mungbean (Vigna radiata (L.)Wilczek) landraces based on SDS-PAGE of total seed storage protein.M.Tech.(Biotech.) Thesis, Dept. of Biotech., SIET, Visveswaraya Technological Univ., Tunkur, Karnataka, p. 28-30.

Polignano GB, Splendido R, Perrino P. 1990. Seed storage proteins diversity in faba bean (Vicia faba L.) entries from Ethiopia and Afghanisthan. Journal of Genetics \& Breeding 44: 31-38.

Roy M N, Mandal N and Das P K. 2001.Seed protein characterization and isozyme diversity for cultivar identification in grasspea (Lathyrus sativus L.). Indian Journal of Genetics \& Plant Breeding 61: 246-249.

Sai-Ut SS, Ketnawa S, Chaiwut P and Rawdkuen S. 2009. Biochemical and functional properties of proteins from red kidney, navy and adzuki beans. Asian 
Journal of Food \& Agro-Industry 2(4): 493504

Sokal RR and Michener CD. 1958. A statistic method for evaluating systematic relationships. University Kansas Scientific Bulletin 28:1409-1438.

Thakare RG, Gadgil JD and Mitra R. 1988. Origin and evolution of seed protein genes in Vigna mungo and Vigna radiata. In: S ShanmugaSundaram, BT McLean (eds.) Proc. 2nd Int. Symp. Mungbean AVRDC Taiwan, pp. 47-52.

Tomooka N, Lairungreang C, Nakeeraks P and Egawa YTC. 1992. Centre of genetic diversity and dissemination pathway in mungbean deduced from seed protein electrophoresis, Theoretical \& Applied Genetics 83: 289-293.

Tripathy SK, Sardar SS, Lenka D and Sahoo S 2010a.Genetic diversity of mungbean (Vigna radiata (L.) Wilczek) genotypes based on SDS-PAGE of albumin seed storage protein. Legume Research 33(1): 54-57.
Tripathy SK, Sardar SS, Mishra DR and Sahoo S. 2010b.Genetic diversity of mungbean (Vigna radiata (L.) Wilczek) genotypes based on SDS-PAGE of globulin seed storage protein Environment \& Ecology 28(3A): 1798-1800.

Tripathy SK, Sardar SS and Mishra PK. 2010c. Analysis of seed storage protein pattern: a method for studying genetic variation and diversity among Vigna genotypes. Indian Journal of Plant Breeding \& Genetics 70(2): 140-144.

Yuzbasioglu E Acik and Ozcan S. 2008. Seed protein diversity among lentil cultivars. Biologia Plantarum 52: 126-128. 